\title{
PRODUCTION OF LIPASE EXTRATED FROM AQUEOUS WASTE: ENZYMATIC ACTIVITY KINETICS
}

\author{
Produção de lipase extraída de resíduos aquosos: \\ cinética da atividade enzimática
}

Tatianne Ferreira de Oliveira' ${ }^{1}$ Maria Raquel Hidálgo² ${ }^{2}$ Manoel Soares Soares Júnior ${ }^{3}$

\begin{abstract}
Lipases are an important group of enzymes with various applications in the food, chemical and pharmaceutical industry, besides having great interest for the treatment of effluents with high lipid content. The objective of this study was to isolate, characterize and select lipolytic bacteria that produce lipase from aqueous waste effluents and to study the enzymatic activity kinetics of the extract obtained via submerged fermentation. The results obtained are promising, being possible to isolate and characterize 23 lipase-producing microorganisms, mostly gram-positive bacteria, but after the fermentation step in a liquid medium, gram negative bacteria showed the highest enzymatic activity (56.72 U.L-1 for STP 2A bacterium and 81.99 U.L ${ }^{-1}$ for R2B). In the enzymatic activity kinetic study with the selected bacterium (R2B), among the six variables (temperature, $\mathrm{pH}$, minimal mineral medium, soybean oil, glucose and sodium nitrate), temperature was the one that most positively influenced the enzymatic activity, and the best results were obtained at $40^{\circ} \mathrm{C}$. It was concluded that the enzyme extract obtained from environmental waste may be used to treat the effluent and contribute to reduce environmental impacts.
\end{abstract}

Index terms: Microbial extract, effluent treatment, sustainability.

\section{RESUMO}

As lipases são um importante grupo de enzimas com diversas aplicações na indústria alimentar, química e farmacêutica, além de ter grande interesse para o tratamento de efluentes com alto teor de lipídios. Objetivou-se, neste trabalho, isolar, caracterizar e selecionar bactérias lipolíticas produtoras de lipase, a partir de efluentes residuais aquosos, assim como estudar a cinética da atividade enzimática do extrato obtido via fermentação submersa. Os resultados obtidos foram promissores, sendo possível isolar e caracterizar 23 microrganismos potencialmente produtores de lipase, sendo a maioria das bactérias Gram Positivas, porém após a etapa de fermentação em meio líquido, os Gram Negativos apresentaram as maiores atividades enzimáticas $\left(56,72\right.$ U.L ${ }^{-1}$ para a bactéria ETE 2A e 81,99 U.L-1 para a R2B). No estudo cinético da atividade enzimática com a bactéria selecionada (R2B), das seis variáveis (temperatura, $\mathrm{pH}$, meio mínimo mineral, óleo de soja, glicose, e nitrato de sódio), a temperatura foi a que mais influenciou na atividade enzimática, tendo efeito positivo, e os melhores resultados foram obtidos a $40^{\circ} \mathrm{C}$. Concluiu-se que o extrato enzimático obtido, a partir de resíduos ambientais, poderão ser utilizados no próprio tratamento do efluente e contribuir na redução dos impactos ambientais.

Termos para indexação: Extrato microbiano, tratamento de efluentes, sustentabilidade.

\section{INTRODUCTION}

Lipases (triacylglycerol acylhydrolases, EC3.1.1.3) are water-soluble enzymes that catalyze the hydrolysis of ester bonds of insoluble triacylglycerols, releasing free fatty acids, mono-or diacylglycerolin into the oil-water interface (Treichel et al., 2010). These enzymes catalyze a wide range of reactions such as hydrolysis, esterification, trans-esterification, alcoholysis, acidolysis and aminolysis (Joseph; Ramteke; Thomas, 2008), and may be of animal, microbial or plant origin, with variations in catalytic properties, and can be obtained by solid-state fermentation or submerged fermentation (Annibale et al., 2006; Rigo et al., 2010; Papagora; Roukas; Kotzekidou, 2013).

Lipases are an important group of enzymes with various applications in the food, chemical and pharmaceutical industry, besides having great interest for the treatment of effluents with high lipid content (Jeganathan; Nakhla; Bassi, 2007; Ertugrul; Donnez; Takac, 2007). The use of lipases in effluents with high lipid content aims to hydrolyze triacylglycerides, reducing levels of suspended solids and lipids, thus avoiding the formation of oil films in pipelines. The use of enzymes in environmental biocatalysis meets the strong tendency of governments to intensify constraints to environmental

${ }^{1}$ Universidade Federal de Goiás/UFG - Escola de Agronomia e Engenharia de Alimentos - Km 0 - Cx. P. 131 - $74690-900$ - Goiânia - GO - Brasil ferreira.tatianne@yahoo.com.br

²Universidade Federal de Goiás/UFG - Escola de Nutrição/Laboratório de Microbiologia - Goiânia - GO - Brasil

¿Universidade Federal de Goiás/UFG - Escola de Agronomia e Engenharia de Alimentos - Goiânia - GO - Brasil

Received in april 25, 2014 and approved in september 1, 2014

Ciênc. Agrotec., Lavras, v.38, n.6, p.562-572, nov./dez., 2014 
pollution. However, the high cost of commercial enzymes makes commercial enzyme treatment very expensive. Thus, the search for low-cost treatment in addition to the use of effluents has increased the interest in the production of enzyme extracts with high yields (Leal; Freire; Sant'Anna, 2002; Salihu et al., 2012).

The production of lipases requires the study of fermentation conditions, relating carbon and nitrogen sources to temperature and $\mathrm{pH}$ conditions (Silva et al., 2005; Matsuoka; Miura; Hori, 2009). Some studies have reported the use of some low-cost substrates in the production of enzyme extracts such as soybean oil and food industry by-products as an alternative to reduce production costs and contribute to agro-industrial sustainability (Kona; Qureshi; Pai, 2001; Nascimento et al., 2007). Other studies have reported that lipase production by bacterial strains is the most common, and these generally have higher enzymatic activities of fungi, are often thermostable and mostly extracellular, thus facilitating their extraction from the fermented medium (Hasan; Shab; Hameed, 2006; Li; Zong, 2010).

In addition, the use of the effluent in the production of lipases is an alternative to reduce the enzyme production cost, allied to the fact of using the effluent. The production of lipases using the effluent may be feasible, since it has a high load of nutrients still available for microbial growth and enzyme extract production.

The presence of lipids in the effluent enables the production of lipases, since these are used as a carbon source for microbial growth (Rodeva; Hemkemeier; Colla, 2010). Thus, the aim of this study was to isolate and characterize strains of lipolytic bacteria that produce lipase from aqueous waste for later use in the treatment of agro-industrial effluents waste and to study the enzymatic activity kinetics of the extract obtained via submerged fermentation.

\section{MATERIAL AND METHODS}

\section{Effluent}

The effluents used for the isolation of lipolytic bacteria were collected in $1 \mathrm{~L}$ bottles properly sterilized in the local Sewage Treatment Plant (STP) in two distinct points: grease trap and anaerobic treatment tank, and also in the residential grease trap, both of Goiânia - GO, Brazil.

\section{Microbial enrichment of the oily residue}

The three effluents collected were divided into two samples: A1 (pure effluent) and A2 (enriched effluent). A $20-\mathrm{ml}$ aliquot of the residue was transferred to a $250 \mathrm{ml}$
Erlenmyer flask containing $100 \mathrm{ml}$ of minimal mineral medium (MMM), 10\% (v/v) of commercial soybean oil (Liza, Cargill, Brazil) and 1\% (v / v) of fungicide Nystatin (Germed, Orlândia, Brazil). One liter of MMM has $1.0 \mathrm{~g}$ $\mathrm{NaCl}, 5.0 \mathrm{~g}\left(\mathrm{NH}_{4}\right) \mathrm{SO}_{4} 6.2 \mathrm{~g} \mathrm{Na}_{2} \mathrm{HPO}_{4}, 0.3 \mathrm{~g} \mathrm{MgSO}_{4} .7 \mathrm{H}_{2} \mathrm{O}$ and $0,9 \mathrm{~g} \mathrm{KH}_{2} \mathrm{PO}_{4}$. The flasks were incubated on a rotary shaker (Tecnal, TE -184, Piracicaba, Brazil) at $30^{\circ} \mathrm{C}, 120$ rpm for $96 \mathrm{~h}$. So the test was conducted in a completely randomized design with a $3 \times 2$ factorial arrangement, totaling six treatments and two original replicates, amounting to twelve reactors in this enrichment step.

\section{Isolation and selection of lipolytic bacteria}

For microbial isolation, $20 \mu \mathrm{L}$ of each treatment were transferred to Petri dishes (striae inoculation technique) containing $40 \mathrm{ml}$ of solidified MMM, 0.1\% $\mathrm{v} / \mathrm{v}$ nystatin (fungal growth inhibitor), 5\% refined soya oil emulsified with $1 \%$ v/v Tween 80 (Neon, São Paulo, Brazil) and $1 \% \mathrm{v} / \mathrm{v}$ indicator Rhodamine B (Inlab, São Paulo, Brazil), according to methodology proposed by Papagora, Roukas and Kotzekidou (2013). The plates were kept in an incubator at $30^{\circ} \mathrm{C}$ for $96 \mathrm{~h}$. Two replicates for each plate and a negative control for each treatment were performed. After this period, the colonies were submitted to UV light of $350 \mathrm{~nm}$ with the aid of a UV chamber (Prodicil, Curitiba, Brazil). Those that exhibited fluorescent orange halo were identified as lipolytic bacteria and isolated on nutrient agar (Rodrigues et al., 2010; Papagora; Roukas; Kotzekidou, 2013).

\section{Characterization of microorganisms}

The colonies previously selected as positive in the rhodamine test (exhibited fluorescent orange halo) were submitted to the Gram test and to biochemical tests for catalase, coagulase, indole and methyl red (MR) according to methodology proposed by Hajdenwurcel (1998) and Sneath, Mair and Sharpe (1986). Negative control was performed with Escherichia Coli (Gram negative) and Staphylococcus Aureus (Gram positive) strains.

\section{Production of enzyme extract via submerged fermentation}

The microorganisms previously selected as lipolytic bacteria were used for the production of the enzyme extract in liquid medium. Fermentations were carried out in reactors with capacity of $125 \mathrm{ml}$, where $40 \mu \mathrm{L}$ of each strain was transferred to two different substrates to obtain the following enzymatic extracts: S1 (pure effluent) and $\mathrm{S} 2$ (minimum mineral medium $(\mathrm{MMM})+$ soybean oil $(5 \% \mathrm{v} / \mathrm{v})$. Reactors were incubated at $30^{\circ} \mathrm{C}$ for $72 \mathrm{~h}$ 
under stirring (50 rpm) in water bath (Tecnal, TE -184, Piracicaba, Brazil). Upon completion of fermentation, the extraction of extracellular enzymes took place. One aliquot of $10 \mathrm{ml}$ of each reaction medium was centrifuged (TG 16-WS Tabletop High Speed Centrifuge) at $2000 \mathrm{rpm} \mathrm{min}^{-1}$ for $15 \mathrm{~min}$. Supernatants were used as enzyme extract for analysis of the enzymatic activity.

\section{Enzymatic activity determination}

The enzymatic activity was determined by spectrophotometric method (Spectrophotometer photonics BEL, Monza, Italy) according to methodology described by Parul, Sulakshana and Gupta (2005) which is based on the hydrolysis of p-nitrophenyl palmitate ( $\mathrm{p}$-NPP), resulting in a yellow color that is enhanced in alkaline pHs. About $30 \mathrm{mg}$ of $\mathrm{p}$-NPP (Sigma) were dissolved in $10 \mathrm{~mL}$ of isopropanol (Neon, São Paulo, Brazil) and $207 \mathrm{mg}$ of sodium deoxycholate (Sigma, city, country) and $100 \mathrm{mg}$ of gum arabic (Synth, city, country) in $90 \mathrm{~mL}$ of phosphate buffer solution ( $\mathrm{pH}$ 8.0). Then $2.4 \mathrm{ml}$ of this substrate solution was added to $100 \mu \mathrm{L}$ of sample. The mixture was incubated for $15 \mathrm{~min}$ in water bath at $37^{\circ} \mathrm{C}$ and readings were made in spectrophotometer at $410 \mathrm{~nm}$. Enzymatic activity unit (U) was defined as $1 \mu \mathrm{mol}$. min $^{-1}$ of $\mathrm{p}$ - nitrophenol released from the substrate, according to equation 1 :

$$
U=\frac{A b s \times V o l}{\in \times T \times p}
$$

Where: Abs: Absorbance a $410 \mathrm{~nm}$; Vol: volume of substrate solution $(\mathrm{mL}) ; \varepsilon$ : molar extinction coefficient of p-nitrophenol $\left(18,5 \mathrm{~mL} \mu \mathrm{mol}^{-1} \mathrm{~cm}^{-1}\right), T$ temperatura $\left({ }^{\circ} \mathrm{C}\right)$; $p$ : volume of sample $(\mathrm{mL})$.

\section{Enzymatic activity kinetics}

The lipolytic bacteria that showed the highest enzymatic activity was used in the kinetic study that determined the enzymatic activity. Six variables were evaluated: $\mathrm{pH}$, temperature and components of the culture medium as MMM, soybean oil, glucose and sodium nitrate $\left(\mathrm{NaNO}_{3}\right)$. The reactors were incubated at different temperatures $\left(20,30\right.$ and $\left.40^{\circ} \mathrm{C}\right)$ under stirring $(50 \mathrm{rpm})$ in water bath, and the enzymatic activity was measured at times of 24, 30, 48, 53 and 72 hours of fermentation. The experimental design (levels of variation -1 to +1 ) totaled 18 experiments (Table 1 ). The results were submitted to analysis of variance, and the effect of variations was estimated with the aid of the Statistica 7.0 software.

\section{RESULTS AND DISCUSSION}

\section{Isolation and selection of lipolytic microorganisms}

From the media used for the isolation of strains, twenty three microorganisms were isolated, seven from residential grease trap (R), sixteen from STP (eight from the grease trap (STP) and eight from the treatment tank $(\mathrm{T})$ ). The encoding used for the isolated microorganisms were : R1A, R1B, R1B', R2A, R2A', R2B, R2B', STP1A, STP1A', STP1B, STP1B', STP2A, STP2A', STP2B, STP2B', T1A, T1A', T1B, T1B', T2A, T2A', T2B, T2B', being, respectively, R1/STP1/ $\mathrm{T} 1$ (pure effluent) and R2/STP2/T2 treatment T2 (enriched effluent). Figure 1A shows the plates used for selection of lipolytic bacteria, showing fluorescent orange coloration around colonies. It was also observed that the pre-enriched reactors showed higher number of colonies (left plate in figure 1B), but this result should be confirmed (the next step) with the enzymatic activity of isolated and fermented strains.

\section{Characterization of bacteria, fermentation and enzyme extract}

Table 2 shows the results of biochemical characterization and Gram test and table 3 shows the results of the enzymatic activity of the 23 previously selected microorganisms, where each bacterium was fermented on two different substrates S1 (pure effluent) and S2 (mineral minimal culture medium supplemented with 5 $\%$ soybean oil). The characterization results revealed that the majority of bacteria from aqueous waste was classified as Gram positive, and only four were classified as Gram negative (STP 2A', T1A, R1B' and R2B). According to Semionato (2006) the lipolytic bacteria isolated from grease trap were Gram negative bacteria belonging to genus Pseudomonas, which produced extracellular lipase. However, a wide range of bacteria characterized as gram-positive (Burkoholderia glumae, Staphylococcus aureus, Staphylococcus xylosus produce lipase on an industrial scale (Messias et al., 2011). In relation to colony morphology, the bacteria showed different morphologies (rods, cocci and bacillus). Biochemical tests revealed that all are coagulase positive, mostly positive catalase (with the exception of T1B') and negative indole. Regarding the methyl red test, the results revealed a balance between positive and negative. According to Winn et al. (2010), Gram positive bacteria may have positive or negative catalase and / or positive or negative coagulase. These results allow a better characterization of the type of lipolytic bacterium isolated from aqueous wastes. 
Tabela 1 - The experimental design - Levels of variables on the enzymatic activity kinetics.

\begin{tabular}{|c|c|c|c|c|c|c|}
\hline Experiment & MMM & Soybean Oil (mL) & Glucose (mL) & $\mathrm{pH}$ & Temperature & Sodium nitrate $(\mathrm{mL})$ \\
\hline 1 & -1 & -1 & -1 & -1 & -1 & -1 \\
\hline 2 & 1 & -1 & -1 & -1 & 1 & -1 \\
\hline 3 & -1 & 1 & -1 & -1 & 1 & 1 \\
\hline 4 & 1 & 1 & -1 & -1 & -1 & 1 \\
\hline 5 & -1 & -1 & 1 & -1 & 1 & 1 \\
\hline 6 & 1 & -1 & 1 & -1 & -1 & 1 \\
\hline 7 & -1 & 1 & 1 & -1 & -1 & -1 \\
\hline 8 & 1 & 1 & 1 & -1 & 1 & -1 \\
\hline 9 & -1 & -1 & -1 & 1 & -1 & 1 \\
\hline 10 & 1 & -1 & -1 & 1 & 1 & 1 \\
\hline 11 & -1 & 1 & -1 & 1 & 1 & -1 \\
\hline 12 & 1 & 1 & -1 & 1 & -1 & -1 \\
\hline 13 & -1 & -1 & 1 & 1 & 1 & -1 \\
\hline 14 & 1 & -1 & 1 & 1 & -1 & -1 \\
\hline 15 & -1 & 1 & 1 & 1 & -1 & 1 \\
\hline 16 & 1 & 1 & 1 & 1 & 1 & 1 \\
\hline 17 & 0 & 0 & 0 & 0 & 0 & 0 \\
\hline 18 & 0 & 0 & 0 & 0 & 0 & 0 \\
\hline
\end{tabular}

MMM: Minimal mineral medium (mL).
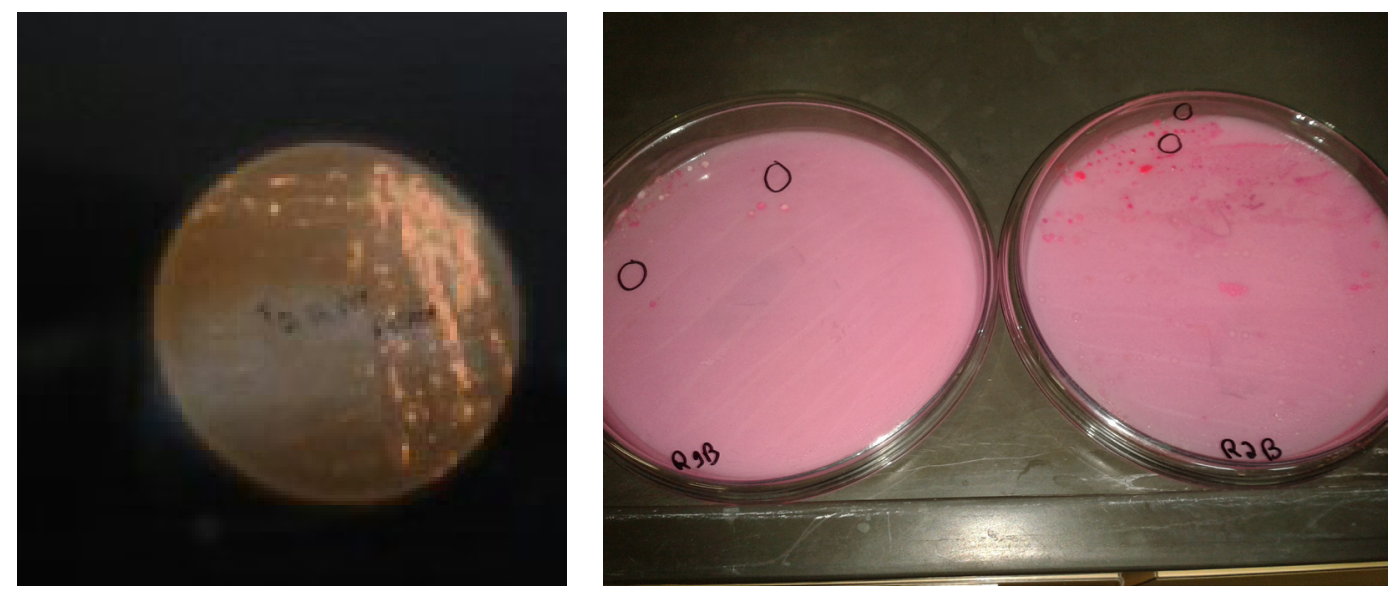

Figure 1 - Selection of lipolytic bacteria with the aid of UV chamber, $\mathrm{A}=$ fluorescent orange coloration around colonies, $\mathrm{B}=$ plates with colonies of bacteria R1B and R2B.

The enzymatic activity results showed that microorganisms with increased lipolytic activity were those grown on substrate S2 (mineral minimal culture medium supplemented with $5 \%$ soybean oil). Microorganisms grown on substrate 1 (pure effluent) did not reach high enzyme activity, indicating the importance of the culture medium in the production of microbial lipase. For example, T2A and R2A microorganisms obtained enzymatic activities respectively $37 \%$ and $55 \%$ greater than when grown on 
$\mathrm{S} 2$. In this context, the lipolytic bacteria that obtained the highest enzymatic activities were STP2A', STP2B, $\mathrm{T} 2 \mathrm{~A}$ and $\mathrm{R} 2 \mathrm{~B}$, originating from different waste sources such as grease trap from the STP and also residential grease trap, demonstrating the strong potential of this waste in the sustainable production of lipases, which could be subsequently used in the treatment of this effluent.

These results also show that Gram-negative bacteria had higher enzymatic activity (STP2A', R2B), which is consistent with some authors such as Semionato (2006), who obtained for lipolytic Gramnegative bacteria belonging to genus Pseudomonas increased production of extracellular lipase. These authors also showed that some lipolytic bacteria can be Gram positive such as Clostridium, Bacillus and Staphylococcus; however, the lipolytic activity of these bacteria is less significant than that of Gram-negative bacteria. These results are similar to those obtained by Rocha et al. (2013) and Matsumiya et al. (2007), who isolated microorganisms with high potential for lipase production from aqueous waste and obtained better results with Gram negative bacteria.

According to results obtained in this first step of enzymatic activity quantification in the production of the enzyme extract, bacterium R2B and culture medium $\mathrm{S} 2$ were selected. In this context, the variables that could affect the fermentation process for the production of enzyme extract were studied by the enzyme activity kinetics.

Table 2 - Biochemical characterization of selected lipolytic bacteria.

\begin{tabular}{ccccccc}
\hline Lipolytic bacteria & GRAM & Form & V.M. & Indol & Catalase & Coagulase \\
\hline STP 1A & + & bastonet & - & - & $\mathrm{P}$ & $\mathrm{P}$ \\
STP 1A' & + & bastonet & + & + & $\mathrm{P}$ & $\mathrm{P}$ \\
STP 1B & + & cocci & - & - & $\mathrm{P}$ & $\mathrm{P}$ \\
STP 1B' & + & cocci & - & - & $\mathrm{P}$ & $\mathrm{P}$ \\
STP 2A & + & diplococci & + & + & $\mathrm{P}$ & $\mathrm{P}$ \\
STP 2A' & - & cocci & + & - & $\mathrm{P}$ & $\mathrm{P}$ \\
STP 2B & + & bastonet & - & - & $\mathrm{P}$ & $\mathrm{P}$ \\
STP 2B' & + & cocci & + & - & $\mathrm{P}$ & $\mathrm{P}$ \\
T 1A & + & cocci & - & - & $\mathrm{P}$ & $\mathrm{P}$ \\
T 1A' & - & bacilli & - & - & $\mathrm{P}$ & $\mathrm{P}$ \\
T 1B & + & cocci & - & - & $\mathrm{P}$ & $\mathrm{P}$ \\
T 1B' & + & cocci & - & - & $\mathrm{N}$ & $\mathrm{P}$ \\
T 2A & + & cocci & + & - & $\mathrm{P}$ & $\mathrm{P}$ \\
T 2A' & + & bacilli & - & + & $\mathrm{P}$ & $\mathrm{P}$ \\
T 2B & + & cocci & + & - & $\mathrm{P}$ & $\mathrm{P}$ \\
R 1A & + & cocci & + & - & $\mathrm{P}$ & $\mathrm{P}$ \\
R 1A' & had & no microbial growth & & & & $\mathrm{P}$ \\
R 1B & + & cocci & - & - & $\mathrm{P}$ & $\mathrm{P}$ \\
R 1B' & - & bastonet & - & + & $\mathrm{P}$ & $\mathrm{P}$ \\
R 2A & + & cocci & + & + & $\mathrm{P}$ & \\
R 2A' & + & bacilli & + & + & $\mathrm{P}$ \\
R 2B & - & cocci & + & + & + & $\mathrm{P}$ \\
R 2B' & + & cocci & + & + & - & \\
\hline
\end{tabular}

V. M. Methyl red test; R1/STP1/T1 treatment T1 (pure effluent) and R2/STP2/T2 treatment T2 (enriched effluent). 
Table 3 - Enzymatic activity (EA) of lipolytic bacteria after culture in liquid medium using two different substrates at $30^{\circ} \mathrm{C}$ for $72 \mathrm{~h}$.

\begin{tabular}{cccc}
\hline Bacteria grown on S1 & E.A. $\left(\mathrm{U}^{-\mathrm{L}^{-1}}\right)$ & Bacteria grown on 2 & E.A. $\left(\mathrm{U}^{-\mathrm{L}^{-1}}\right)$ \\
\hline S1 ETE1A & 12.12 & S2 ETE1A & 13.70 \\
S1 ETE1A' & 3.14 & S2 ETE1A' & 23.64 \\
S1 ETE1B & 0.12 & S2 ETE1B & 23.48 \\
S1 ETE1B' & 2.00 & S2 ETE1B' & 9.58 \\
S1 ETE2A & 0.21 & S2 ETE2A & 34.28 \\
S1 ETE2A' & 0.97 & S2 ETE2A' & 56.72 \\
S1 ETE2B & 3.45 & S2 ETE2B & 52.84 \\
S1 ETE2B' & 0.46 & S2 ETE2B' & 44.03 \\
S1 T1A & 21.02 & S2 T1A & 27.25 \\
S1 T1A' & 18.79 & S2 T1A' & 18.19 \\
S1 T1B & 8.21 & S2 T1B & 52.33 \\
S1 T1B' & 4.46 & S2 T1B' & 49.71 \\
S1 T2A & 40.76 & S2 T2A & 55.10 \\
S1 T2A' & 44.73 & S2 T2A' & 30.31 \\
S1 T2B & 4.39 & S2 T2B & 35.21 \\
S1 T2B' & 28.30 & S2 T2B' & 16.90 \\
S1 R1A & 0.68 & S2 R1A & 18.41 \\
S1 R1B & 5.88 & S2 R1B & 29.29 \\
S1 R1B' & 0.87 & S2 R1B' & 21.71 \\
S1 R2A & 22.29 & S2 R2A & 43.82 \\
S1 R2A' & 5.67 & S2 R2A' & 48.56 \\
S1 R2B & 0.28 & S2 R2B & 81.99 \\
S1 R2B' & 10.15 & S2 R2B' & 38.63 \\
\hline
\end{tabular}

STP (Grease trap from the Sewage Treatment Plant), T (treatment tank) and R (residential grease trap), S1 (culture medium: pure effluent) and S2 (culture medium: minimal mineral medium + soybean oil).

\section{Enzyme Activity Kinetics}

Table 4 shows the results of the enzyme activity kinetics obtained by fermentations conducted with bacterium R2B. These results show that for all reactors studied in all experimental conditions, the enzymatic activity reached a peak between $48-53 \mathrm{~h}$ of fermentation and this value decreased after 72 hours of experiment. Figure 2 shows this decrease in reactors $1-4$. These values indicate that there was increased production of enzymes at the exponential phase and early stationary growth phase, as also reported by Bussamara et al. (2010).

According to data obtained (Table 5), it was demonstrated that among the six variables studied to obtain the enzyme extract to be used in wastewater treatment, temperature was the variable that most influenced the enzymatic activity results. In fermentation times of 24 , 30 , and 72 , the temperature always had a positive effect, which means that when temperature increased, the enzyme activity also increased. These results were confirmed by the high lipolytic activity of reactors $3-5$ at $40^{\circ} \mathrm{C}$ (Figure 3). Bussamara et al. (2010) also observed a direct relationship between enzymatic activity of lipase and temperature, which increased from 30 to $50^{\circ} \mathrm{C}$. The high enzymatic activity at $40^{\circ} \mathrm{C}$ of lipases isolated from aqueous waste bacteria was similar to that obtained by lipases from Gram negative bacteria belonging to genus Pseudomonas studied by Gaur, Gupta and Khare (2008) and also bacteria of genus Klebsiella variicola studied by Willerding at al (2012). 
Table 4 - Enzymatic activity (E.A.) evolution $\left(\mathrm{UL}^{-1}\right)$ in the extraction of lipase from lipolytic bacteria R2B.

\begin{tabular}{rrrrrr}
\hline Experiment & $\begin{array}{c}\text { E.A. } \\
24 \text { hours }\end{array}$ & $\begin{array}{c}\text { E.A. } \\
\text { 30 hours }\end{array}$ & $\begin{array}{c}\text { E.A. } \\
48 \text { hours }\end{array}$ & $\begin{array}{c}\text { E.A. } \\
53 \text { hours }\end{array}$ & $\begin{array}{c}\text { E.A. } \\
72 \text { hours }\end{array}$ \\
\hline 1 & 96.21 & 79.39 & 74.53 & 75.05 & 63.42 \\
2 & 94.51 & 94.89 & 97.44 & 104.00 & 92.42 \\
3 & 105.04 & 112.09 & 133.30 & 121.24 & 103.73 \\
4 & 78.41 & 84.47 & 79.89 & 77.06 & 60.75 \\
5 & 103.77 & 100.51 & 100.41 & 110.22 & 81.27 \\
6 & 72.62 & 79.069 & 84.20 & 83.18 & 78.41 \\
7 & 74.32 & 93.29 & 82.66 & 77.37 & 59.88 \\
8 & 96.34 & 96.11 & 96.26 & 97.42 & 91.63 \\
9 & 71.50 & 80.32 & 84.53 & 78.32 & 54.81 \\
10 & 97.29 & 73.09 & 78.86 & 88.00 & 80.09 \\
11 & 95.88 & 96.98 & 82.21 & 75.48 & 78.51 \\
12 & 72.53 & 86.488 & 86.07 & 77.22 & 64.94 \\
13 & 78.36 & 105.22 & 70.55 & 83.37 & 79.45 \\
14 & 79.26 & 77.47 & 93.96 & 89.122 & 64.38 \\
15 & 91.88 & 86.09 & 77.18 & 76.56 & 73.12 \\
16 & 75.63 & 76.21 & 96.96 & 85.38 & 68.80 \\
17 & 77.10 & 83.32 & 80.40 & 79.32 & 79.84 \\
18 & 77.56 & 74.73 & 76.13 & 79.22 & 78.84 \\
\hline
\end{tabular}

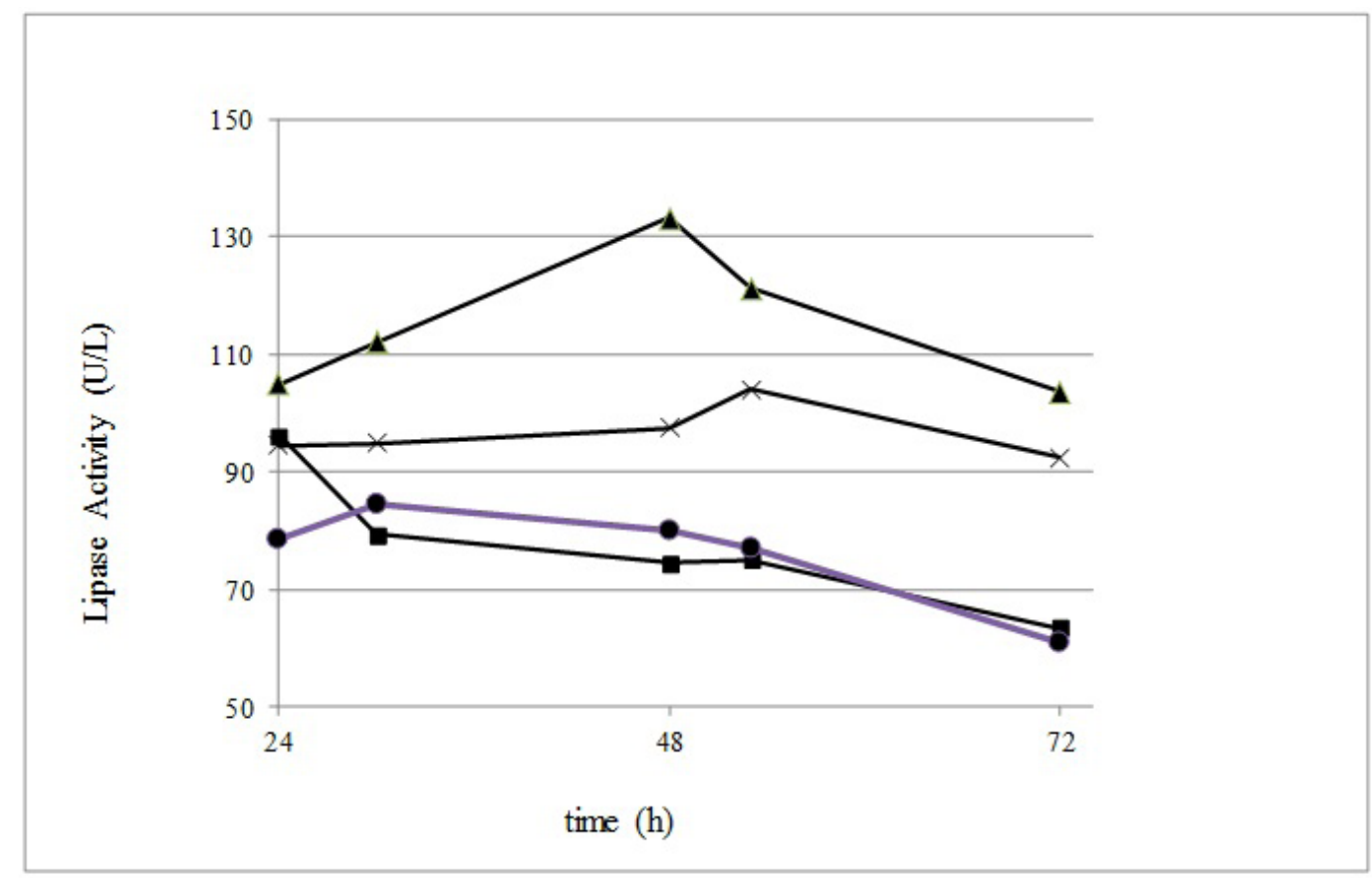

Figure 2 - Enzymatic activity versus time for reactors $1(\boldsymbol{\bullet}), 2(\mathbf{x}), 3(\boldsymbol{\Delta})$ and $4(\bullet)$.

Ciênc. Agrotec., Lavras, v.38, n.6, p.562-572, nov./dez., 2014 
Although the results revealed $\mathrm{pH}$ as a non significant variable $(p>0.05)$, there was a negative trend at all times $(24,30,48,53$ and 72 hours), or when the medium $\mathrm{pH}$ increased, the response, i.e., the enzymatic activity decreased (Figure 4). Some authors such as Matsuoka et al. (2009), consider $\mathrm{pH}$ as an important variable in the extraction process of microbial lipases, thereby having a positive effect on the enzymatic activity of lipases.
The carbon sources (soybean oil and glucose) were not significant in this study, but a negative trend was also verified in some times of the kinetic study. Figure 5 shows the Pareto chart of standardized effects on the response enzymatic activity at $72 \mathrm{~h}$, allowing viewing these effects. Other studies have obtained similar results, where the enzymatic activity of lipase was affected by increased carbon sources such as soybean oil (Hasan-Beikdashti et al., 2012).

Table 5 - Estimation of the effect of variables as a function of the fermentation time on lipase production by bacterium R2B.

\begin{tabular}{lcccccccccc}
\hline Variável & \multicolumn{2}{c}{$24 \mathrm{~h}$} & \multicolumn{2}{c}{$30 \mathrm{~h}$} & \multicolumn{2}{c}{$48 \mathrm{~h}$} & \multicolumn{2}{c}{$53 \mathrm{~h}$} & \multicolumn{2}{c}{$72 \mathrm{~h}$} \\
\cline { 2 - 11 } & Effect & $\mathrm{p}$ & Effect & $\mathrm{p}$ & Effect & $\mathrm{p}$ & Effect & $\mathrm{p}$ & Effect & $\mathrm{p}$ \\
\hline M.M.M. & -0.006294 & 0.236 & -0.010764 & 0.027 & 0.001033 & 0.887 & 0.000473 & 0.931 & 0.000912 & 0.845 \\
O.S. & -0.000432 & 0.933 & 0.005220 & 0.244 & 0.000626 & 0.400 & -0.002943 & 0.593 & 0.000883 & 0.854 \\
Glucose & -0.004900 & 0.350 & 0.000782 & 0.857 & -0.001833 & 0.802 & 0.000782 & 0.886 & -0.000222 & 0.963 \\
pH & -0.007365 & 0.170 & -0.007247 & 0.115 & -0.009799 & 0.198 & -0.011512 & 0.055 & -0.000842 & 0.101 \\
Temperature & 0.137580 & 0.019 & 0.011063 & 0.024 & 0.001162 & 0.132 & 0.016405 & 0.011 & 0.019531 & 0.009 \\
$\mathrm{NaNO}_{3}$ & 0.001098 & 0.831 & -0.004240 & 0.287 & 0.006456 & 0.386 & 0.005115 & 0.359 & 0.000801 & 0.867 \\
\hline
\end{tabular}

$\mathrm{p}$ value $<0.05$ significance level of the variable under study. M.M.M. = Minimal mineral medium; S.O. $=$ soybean oil.

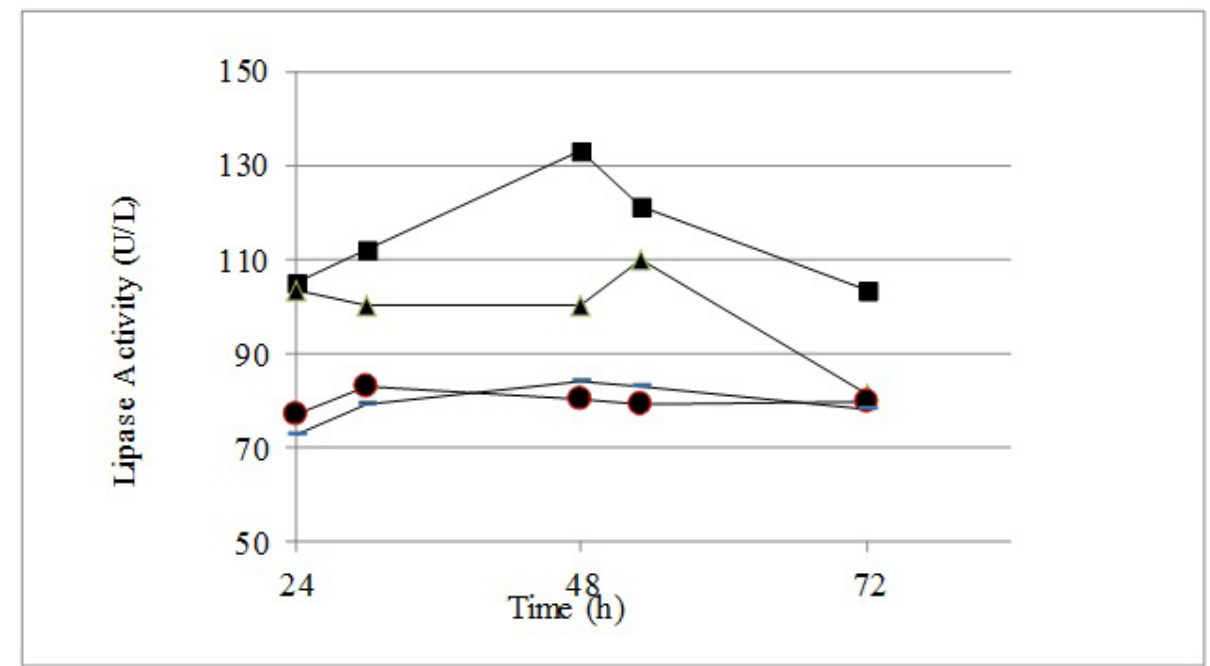

Figure 3 - Effect of temperature on enzyme activity of reactors $3(\boldsymbol{\bullet})$ and $5(\boldsymbol{\Delta})\left(40^{\circ} \mathrm{C}\right)$, reactor $6(-)\left(20^{\circ} \mathrm{C}\right)$ and reactor $17(\bullet)\left(30^{\circ} \mathrm{C}\right)$. 


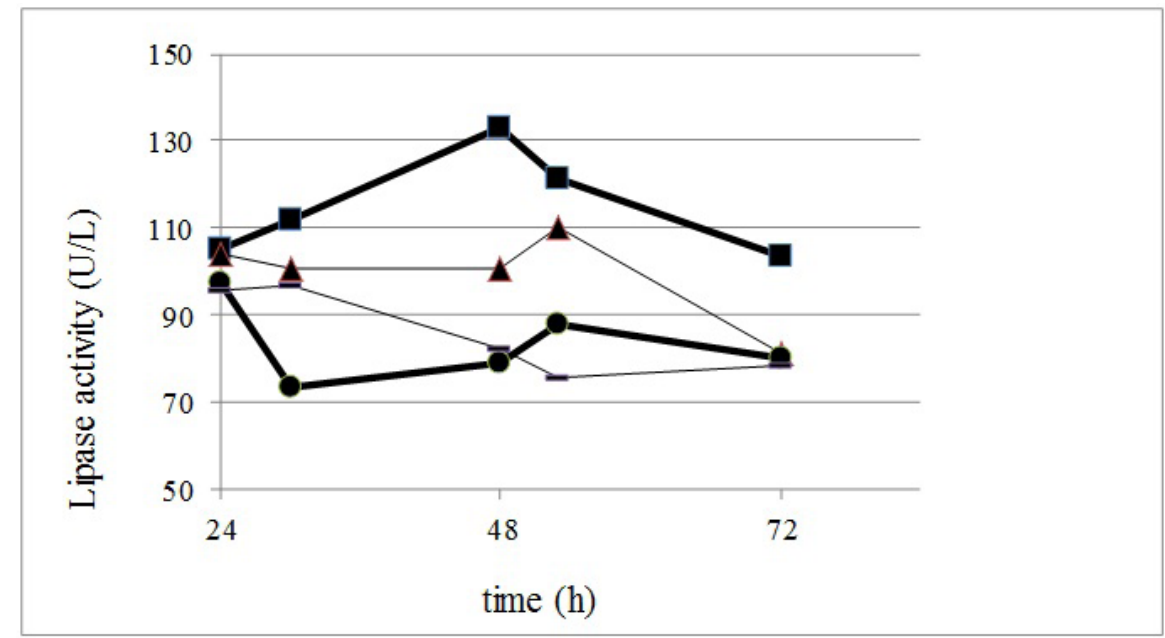

Figure 4 - Effect of $\mathrm{pH}$ on the enzymatic activity of reactors $3(\boldsymbol{\bullet})$ and $5(\boldsymbol{\Delta})(\mathrm{pH} 3.0)$, reactor $10(\bullet)$ and $11(-)(\mathrm{pH}$ $6.0)$, all at $40^{\circ} \mathrm{C}$.

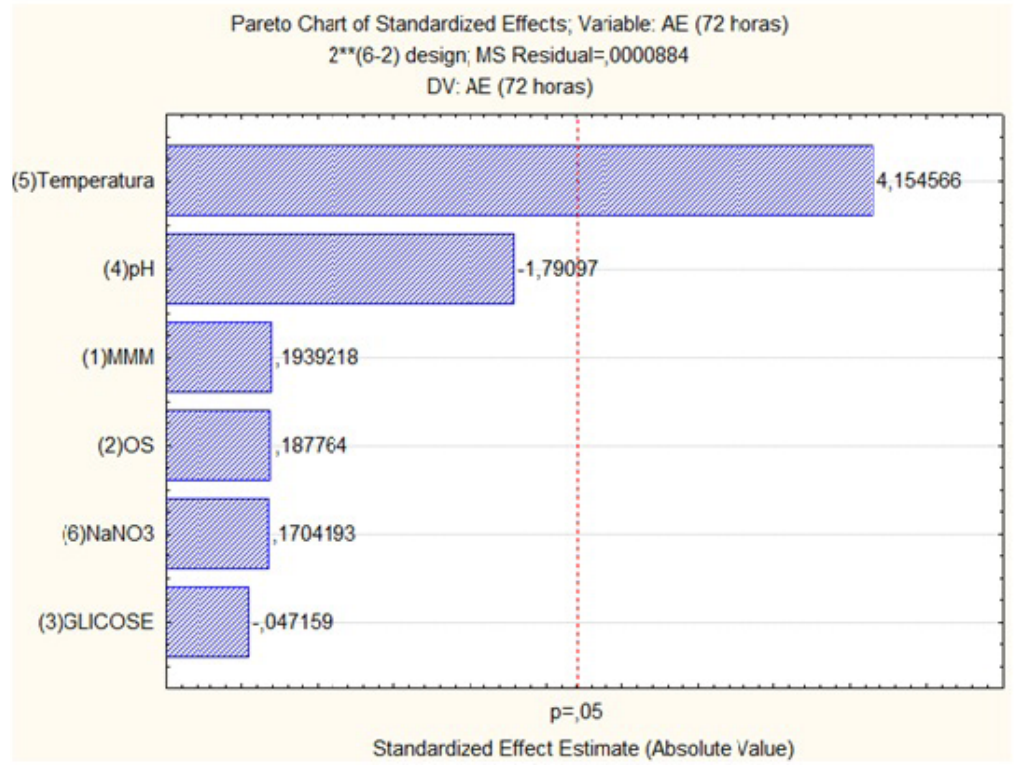

Figure 5 - Pareto chart of standardized effects on the enzymatic activity response.

\section{CONCLUSIONS}

This study demonstrated that it was possible to isolate lipolytic bacteria to be used in the production of lipases from environmental waste. Twenty-three microorganisms were isolated and characterized, and bacterium R2B showed higher enzymatic activity under the conditions studied. The kinetic study demonstrated that temperature was the variable that most influenced the enzymatic activity results, obtaining higher values at $40^{\circ} \mathrm{C}$. There is high potential for the use of domestic aqueous waste in the sustainable production of enzymes, reusing waste in their production process.

\section{ACKNOWLEDGMENTS}

To CNPq - National Council for Scientific and Technological Development - for the scholarship granted to BJT - Atração Jovens Talentos para o Brasil and the local Sewage Treatment Plant for providing the samples. 


\section{REFERENCES}

ANNIBALE, A. et al. Olive-mill wastewater: a promising substrate for microbial lipase production. Bioresource Technology. 97(15):1828-1833, 2006.

BUSSAMARA, R. et al. Isolation of lipase-secreting in a pilot-plant scale batch fermentation. Bioresource Technology. 101(1):268-275, 2010.

ERTUGRUL, S.; DONNEZ, G.; TAKAC, S. Isolation of lipase producting Bacillus sp. from olive mill wastewater and improvising its enzyme activity. Journal of

Hazardous Materials. 149(5):720-724, 2007.

GAUR, R.; GUPTA, A.; KHARE S.K. Purification and characterization of lipase from solvent tolerant Pseudomonas aeruginosa PseA. Process Biochemistry. 43(10):1040-1046, 2008.

HAJDENWURCELL, J.R. Atlas of food microbiology, 1988. 182p.

HASAN, F.; SHAB, A.A.; HAMEED, A. Industrial applications of microbial lipases. Enzyme and Microbial Technology. 39(1):235-251,. 2006.

HASAN-BEIKDASHI, M. et al. Optimization of culture conditions for production of lipase by a newly isolated bacterium Stenotrophomonas maltophilia. Journal of the Taiwan Institute of Chemical Engineers. 43(5):670-677, 2012.

JEGANATHAN, J.; NAKHLA, G.; BASSI, A. Hydrolytic pretreatment of oily wastewater by immobilized lipase. Journal of Hazardous Materials. 145(1-2):127-135, 2007.

JOSEPH, B.; RAMTEKE, P.W.; THOMAS, G. Cold active microbial lipases: some hot issues and recent developments. Biotechnology Advance. 26(5):457-470, 2008.

KONA, R.P.; QURESHI, N.; PAI, J.S. Production of glucose oxidase using Aspergillus niger and corn steep liquor. Bioresource Technology. 78(2):23-126, 2001.

LEAL, M.C.M.R.; FREIRE, D.M.G.; SANT`ANNA, G.L. Hydrolytic enzymes as coadjuvants in the anaerobic treatment of dairy wastewaters. Brazilian Journal of Chemical Engineering. 19(2):175-180, 2002.
LI, N.; ZONG, M. Review: lipases from the genus Penicillium: production, purification, characterization and applications. Journal of Molecular Catalysis B: Enzymatic. 66(2):43-54, 2010.

MATSUMIYA, Y. et al. Isolation and characterization of a lipid-degrading bacterium and its application to lipidcontainig wastewater treatment. Journal of Bioscience and Bioengineering. 103(4):325-330, 2007.

MATSUOKA, H.; MIURA, A.; HORI, K. Symbiotic effects of lipase-secreting bacterium, Burkholderia arboris SL1B1, and a glycerol-assimilating yeast, Candida cylindracea SL1BE, on triacylglycerol degradation. Journal of Bioscience and

Bioengeneering. 107(4):401-408, 2009.

MESSIAS, J.M. et al. Microbial lipases: Production, properties and biotechnological applications.

Semina: Ciências Exatas e Tecnológicas. 32(2):213234, 2011.

NASCIMENTO, W.C.A. et al. Optimization of a culture médium for protease production by Bacillus sp. Thermophilic. Food Science and Technology. 27(2):417-421, 2007.

PAPAGORA, C.; ROUKAS, T.; KOTZEKIDOU, P. Optimization of extracellular lipase production by Debaryomyces hansenil isolates from dry-salted olives using response surface methodology. Food and Bioproducts Processing. 91(4):413-42, 2013.

PARUL, J.; SULAKSHANA, J.; GUPTA, M.N. A microwave-assisted microassay for lipases. Analytical and Bioanalytical Chemistry. 38:1480-1482, 2005.

RIGO, E. et al. Lipase production by solid fermentation of soybean meal with different supplements. Food Science and Technology. 43(7):1132-1137, 2010.

ROCHA, D.C. et al. Selection of microorganisms producer of lipase for fat removal from biodiesel water. Revista Engenharia Agrícola. 33(2):332-340, 2013.

RODEVA, M.; HEMKEMEIER, M.; COLLA, L.M. Evaluation of lipase production using diferent strains of microorganisms isolated from dairy effluent through submerged fermentation. Food Science and Technology. 30(1):126-131, 2010. 
RODRIGUES, G.F. et al. Lipolytic activity of the yeast species associated with the fermentation/storage phase of ripe olive processing. Food Microbiology. 27(5):604-612, 2010.

SALIHU, A. et al. Lipase production: as insight in the utilization of renewable agricultural residues.

Resources, Conservation and Recycling. 58(1):36-44, 2012.

SEMIONATO, S. Evaluation of the lipolytic activity of bacteria isolated from grease removal devices ETE-UFES, 2006, 82p.

SILVA, W.O.B. et al. Production and extraction of an extracellular lipase from the entomopathogenic fungus
Metarhizium anisopliae. Process Biochemistry. 40(1):32-326, jan. 2005.

SNEATH, P.H.A. et al. Bergey`s manual of systematic bacteriology, vol II, 1986. 1599p.

TREICHEL, H. et al. A review on microbial lipases production. Food Bioprocess Technology. 3(2):182196, 2010.

WILLERDING, A.L. et al. Hydrolytic activity of bacterial lipases in Amazonian vegetables oils. Química Nova. 35(3):1782-1786, 2012.

WINN, W. JR. et al. Microbiological diagnosis, 2010. $1565 \mathrm{p}$. 